Article

\title{
Reutealis Trisperma Oil Esterification: Optimization and Kinetic Study
}

\author{
Riky Lim ${ }^{1,2}$, Deog-Keun Kim ${ }^{1, *}$ and Jin-Suk Lee ${ }^{3}$ \\ 1 Biomass and Wastes to Energy Laboratory, Korea Institute of Energy Research, Daejeon 34129, Korea; \\ rikylim@kier.re.kr \\ 2 Renewable Energy Engineering, University of Science and Technology, Daejeon 34113, Korea \\ 3 Gwangju Bio/Energy R\&D Center, Korea Institute of Energy Research, Gwangju 61003, Korea; \\ bmjslee@kier.re.kr \\ * Correspondence: dkkim@kier.re.kr; Tel.: +82-042-860-3552
}

Received: 30 January 2020; Accepted: 19 March 2020; Published: 23 March 2020

\begin{abstract}
Reutealis trisperma, due to its high kernel-oil yield ( $\pm 50 \%$ ) and long productivity ( \pm 70 years), is considered to be a promising feedstock for biodiesel production. In addition, this plant, which can thrive on marginal lands, is classified as a non-edible oil since it contains a toxin known as eleostearic acid. The present study aimed to optimize the esterification step in biodiesel production from R.trisperma oil catalyzed using sulfonic ion exchange resin Lewatit K2640. The optimization step was performed using a response surface methodology through the incorporation of a central composite design. A kinetic study was performed as well, based on the assumption of a pseudo-homogeneous second-order model. Catalyst loading was found to have the most significant impact on acid value, followed by temperature and methanol-to-oil molar ratio. The optimal conditions for the esterification step were $92{ }^{\circ} \mathrm{C}$ temperature, $5.34 \%$ catalyst loading, and 5.82:1 methanol-to-oil molar ratio. The acid value and FFA conversion of R.trisperma oil under these conditions were $2.49 \mathrm{mg} \mathrm{KOH} / \mathrm{g}$ and $91.75 \%$, respectively. The kinetics study revealed that the constructed model could fit the experimental data well with relatively high reliability. The activation energy required for the esterification of R.trisperma oil was $33.2 \mathrm{~kJ} / \mathrm{mol}$.
\end{abstract}

Keywords: biodiesel; Reutealis trisperma; esterification; optimization; kinetics

\section{Introduction}

Our world is highly reliant on a single source of energy, fossil fuel. Cheapness, cost effectiveness, and wide accessibility are some of the recognizable advantages of fossil fuel. These advantages come at a steep price, however, as the excessive exploitation of fossil fuel has released enormous amounts of greenhouse gases into our atmosphere, leading to global warming. As of 2016, $\mathrm{CO}_{2}$ emissions had reached $32.31 \mathrm{GtCO}_{2}$, almost 2 times greater than the output of the early industrial revolution [1]. In addition, fossil fuel is not a renewable resource, making the need for alternative sources even more urgent.

Whereas the global energy supply is still dominated by fossil fuel, the proportion of renewables has been on the rise, reaching 10.2\% of the primary energy supply in the OECD (Organisation for Economic Co-operation and Development) countries by 2017 [1]. This uptrend is projected to continue as numerous other countries race to increase their utilization of renewables. For instance, South Korea released a plan to its renewables proportion from $6 \%$ to $20 \%$ by 2030 . Following South Korea's step is Indonesia, which plans to increase its renewable proportion from $6.2 \%$ (2016) to $23 \%$ by 2025 .

Biodiesel is a product of a transesterification reaction in which triglycerides found in vegetable oils or animal fats combine with alcohol in the presence of a catalyst to produce fatty acid methyl 
esters (FAME) and glycerol. Biodiesel is considered superior to fossil fuel in terms of biodegradability, renewability, toxicity, ecofriendliness [2], and better physicochemical properties except for those such as freezing point and oxidation stability $[3,4]$. Biodiesel has similar characteristics to petroleum-based diesel, facilitating its incorporation as a mixture or direct utilization with existing technologies without complex modification [5].

Transesterification is widely adapted for biodiesel production because of its relatively mild operating conditions. As it is reversible, excess amounts of reactants can be used to promote the forward reaction and increase product yields thereby. An alkaline catalyst is commonly used in transesterification reaction as it has a faster reaction rate relative to an acid catalyst [6]. However, the transesterification system is highly sensitive to high free fatty acid (FFA) content. High FFA content in feedstock can promote the formation of soap through a saponification reaction, leading to decreased yields and difficulties in the separation and purification of biodiesel. Thus, in systems where high FFA contents are present, an additional pretreatment step to reduce acid value (FFA) level is needed.

Pretreatment of FFA can be achieved using an esterification reaction, in which the FFA is reacted with alcohol in the presence of an acid catalyst to produce FAME and water. Sulfuric acid is commonly used in esterification reactions, given its advantage of high FFA conversion yield under moderate conditions [7]. Unfortunately, sulfuric acid can cause corrosion and environmental problems, making it relatively difficult to utilize on large scales. For these reasons, a heterogeneous catalyst is preferred as it is can be easily recovered and recycled and with less waste production.

The feedstock for biodiesel production usually comes from vegetable oils as they are easier to source on large scales [8]. Palm oil is one of the most extensively utilized vegetable oils in biodiesel production, due to its cheap price, high kernel-oil yield ( $\pm 25 \%)$ [9], and long productivity ( \pm 23 years) [10]. Excessive utilization of palm oil, however, has led to massive deforestation, especially through direct burning, to make room for palm tree plantations. Hence, while biodiesel is considered to be a greener alternative to petroleum fuel, the overall greenhouse gas reduction credit from the use of palm oil is considered to be insignificant due to the enormous amounts of greenhouse gases emitted during the deforestation process. Palm oil also is an edible oil, which makes for competition with the food industry. Thus, researchers have shifted their attention towards other, non-edible feedstock alternatives, such as Jatropha curcas and Pongamia pinnata [11].

Reutealis trisperma is another oil-producing crop that has the potential to be commercialized as a biodiesel production feedstock. This species is native to the Philippines and is cultivated throughout the South East Asia region. Compared to palm trees, R.trisperma has a much higher oil kernel yield $( \pm 50 \%)[12]$ and longer productivity $( \pm 70$ years), making it an especially promising feedstock candidate. It can grow on marginal land, which could help both the restoration of marginal lands and the prevention of deforestation. Furthermore R.trisperma oil is known to contain a toxin called eleostearic acid, making it non-edible [13]. All these factors make R.trisperma a very promising alternative indeed for commercialization as biodiesel production feedstock.

Several studies have been conducted regarding the production of biodiesel from R.trisperma oil. This oil has a relatively high acid value, averaging $30 \mathrm{mg} \mathrm{KOH} / \mathrm{g}$. Thus, an esterification reaction is deemed necessary to maximize the biodiesel production from this oil. A two-step esterification/transesterification reaction of R.trisperma oil produced a 95.15\% biodiesel yield [14]. One study found that the highest FAME yield achieved was 61.1\% [13]. Another study incorporated an infrared-assisted technology for biodiesel production from R.trisperma oil and successfully achieved a $97.78 \%$ methyl ester yield [15]. Several gaps have been detected based on these studies. First, all of these studies performed the esterification reaction with sulfuric acid, which is preferentially avoided for larger-scale production. Second, there is limited data available on the kinetics of R.trisperma oil esterification, which is considered important for scaling up the production process. Hence, to fill that data lacuna, the present study aimed to investigate and optimize the esterification reaction of R.trisperma oil with a heterogeneous ion exchange resin Lewatit K2640. A kinetics study of the esterification reaction was performed as well. 


\section{Materials and Methods}

\subsection{Materials}

R.trisperma oil was kindly provided from Indonesia via air mail. Due to the limited availability of feedstock with the same acid value, however, experiments for the optimization of esterification of FFA and methanol were performed with a model oil made up of oleic acid (99.5\%; Samchun Pure Chemical, Korea) and soybean oil (99.99\%; Daesang, Korea) and synthesized to mimic the average acid value of R.trisperma oil (30 mg KOH/g). Methanol (dried, GR grade) was obtained from Duksan Pure Chemical in Korea. $\mathrm{KOH}(95 \%$, flake) was acquired from OCI Chemical in Korea. Benzene (99.5\%) and ethanol (95\%) were supplied by Samchun Pure Chemical. Methyl heptadecanoate was obtained from Sigma Aldrich (St. Louis, Missouri, USA). Catalyst (Lewatit K2640) was purchased from LANXESS Deutschland GmbH.

\subsection{Methods}

\subsubsection{Preparation of Feedstock}

The model oil was synthesized by mixing oleic acid in soybean oil to mimic the average acid value of R.trisperma oil ( $\pm 30 \mathrm{mg} \mathrm{KOH} / \mathrm{g})$. The R.trisperma oil was pretreated with filtration and water removal to remove solid impurities and the moisture content in the feedstock. The properties of the pretreated R.trisperma oil were characterized in terms of the acid value, water content, impurities, metal ions, and phosphorous content.

\subsubsection{Optimization of Esterification Reaction}

The esterification reactions were performed in a $500 \mathrm{~mL}$ stainless steel reactor equipped with thermocouple, agitator, chiller, and sampling port. The catalyst was contained inside a 4-blade propeller covered in a stainless-steel mesh to prevent the blockage of the sampling port by catalys particles. A schematic of the reactor and a photo of the propeller are provided in Figure 1. The optimization reaction was performed according to the response surface methodology (RSM) via a central composite design. RSM was selected, as it is widely used to optimize a system while observing the effects of input variables, along with their interaction, on the response variable. Specifically, RSM is valuable for evaluation of the topography of the response surface and identification of the optimal conditions of a system. Three input variables (temperature, catalyst loading, and methanol-to-oil molar ratio) were selected as the optimization process factors, as shown in Table 1. Each process factor carried three different levels $(-1,0,1)$ and two axial points $(-1.68$ and +1.68$)$, and the effect of each on the response variable (acid value) was evaluated.

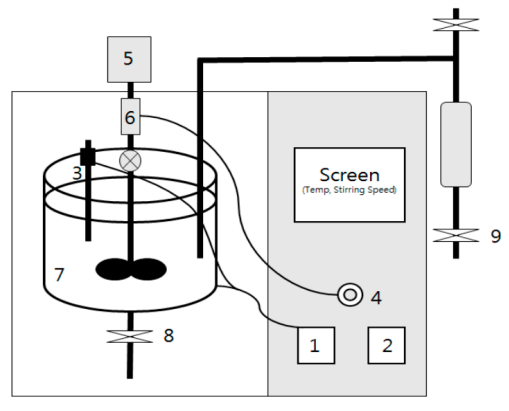

(a)

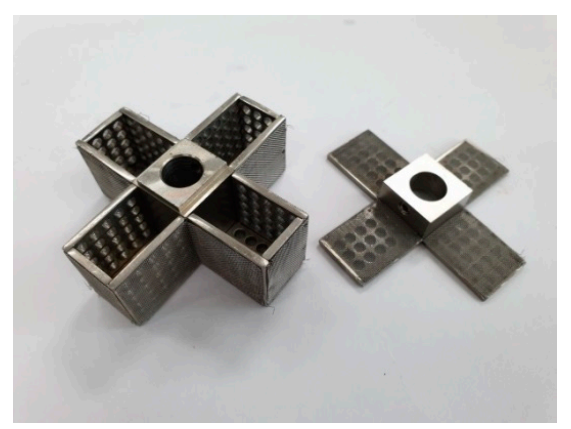

(b)

Figure 1. Equipment used in study. (a) Schematic representation of $500 \mathrm{~mL}$ stainless steel reactor, (1) temperature controller, (2) chiller controller, (3) thermocouple, (4) agitator-speed controller, (5) motor, (6) agitator, (7) reactor vessel, (8) low-temperature sampling port, (9) high-temperature sampling port; (b) 4-blade propeller. 
Table 1. Input variables for optimization of esterification reaction.

\begin{tabular}{ccccccc}
\hline \multirow{2}{*}{ Symbol } & \multirow{2}{*}{ Factor } & \multicolumn{5}{c}{ Levels } \\
\cline { 3 - 7 } & & $-\boldsymbol{\alpha}$ & $\mathbf{- 1}$ & $\mathbf{0}$ & $\mathbf{+ 1}$ & $\mathbf{+}$ \\
\hline $\mathrm{A}$ & Temperature $\left({ }^{\circ} \mathrm{C}\right)$ & 58 & 65 & 75 & 85 & 92 \\
$\mathrm{~B}$ & Catalyst loading $(\% \mathrm{wt})$ & 0.36 & 1 & 3 & 5 & 5.64 \\
$\mathrm{C}$ & Methanol-to-oil molar ratio & 1.74 & 2.64 & 3.97 & 5.29 & 6.18 \\
\hline
\end{tabular}

The esterification reactions were performed with $200 \mathrm{~mL}$ of oil as feedstock. A specific amount of catalyst was put into the propeller blade and heated alongside the feedstock under constant stirring of $300 \mathrm{rpm}$. The heating process was continued for $30 \mathrm{~min}$ before the addition of methanol to the reactor. The experiments were conducted in a randomized manner, as shown in Table 2. The analysis was performed with the help of statistical software Minitab 17 (Minitab, LLC., Pennsylvania, USA). A second-order polynomial equation was constructed based on the experimental data and used as the basis of the optimization step.

$$
y=b_{0}+b_{1} A+b_{2} B+b_{3} C+b_{12} A B+b_{13} A C+b_{23} B C+b_{123} A B C+b_{11} A^{2}+b_{22} B^{2}+b_{33} C^{2}
$$

where y represents the response variable (acid value); $\mathrm{A}, \mathrm{B}$, and $\mathrm{C}$ are the input variables, and $b_{0}, b_{i}, b_{i i}$, $b_{i j}, b_{i j}, b_{i j k}(i=1,2,3 ; j>i$ and $k>j)$ are the regression coefficients respectively. An analysis of variance (ANOVA) was also performed to identify the significance of each factor to the response variable and the fit of the developed model to the experimental data. The optimal conditions were obtained by solving the model equation.

Table 2. Central-composite-design-based experimental variation.

\begin{tabular}{ccccccc}
\hline \multirow{2}{*}{ Run No } & \multicolumn{3}{c}{ Coded Value } & \multicolumn{3}{c}{ Real Value } \\
\cline { 2 - 7 } & $\mathbf{A}$ & $\mathbf{B}$ & $\mathbf{C}$ & $\mathbf{A}\left({ }^{\circ} \mathbf{C}\right)$ & $\mathbf{B}(\mathbf{\%} \mathbf{w t})$ & $\mathbf{C}$ \\
\hline 1 & -1.68 & 0 & 0 & 58.2 & 3 & 3.97 \\
2 & 0 & 0 & 0 & 75 & 3 & 3.97 \\
3 & 1 & -1 & 1 & 85 & 1 & 5.29 \\
4 & 0 & 0 & 0 & 75 & 3 & 3.97 \\
5 & -1 & -1 & -1 & 65 & 1 & 2.64 \\
6 & 0 & 0 & 1.68 & 75 & 3 & 6.18 \\
7 & 1 & 1 & -1 & 85 & 5 & 2.64 \\
8 & 0 & 0 & -1.68 & 75 & 3 & 1.74 \\
9 & 0 & 0 & 0 & 75 & 3 & 3.97 \\
10 & 1 & -1 & -1 & 85 & 1 & 2.64 \\
11 & 0 & -1.68 & 0 & 75 & 0.36 & 3.97 \\
12 & -1 & 1 & -1 & 65 & 5 & 2.64 \\
13 & 1.68 & 0 & 0 & 91.8 & 3 & 3.97 \\
14 & 0 & 0 & 0 & 75 & 3 & 3.97 \\
15 & 0 & 1.68 & 0 & 75 & 5.36 & 3.97 \\
16 & 0 & 0 & 0 & 75 & 3 & 3.97 \\
17 & 0 & 0 & 0 & 75 & 3 & 3.97 \\
18 & 1 & 1 & 1 & 85 & 5 & 5.29 \\
19 & -1 & 1 & 1 & 65 & 5 & 5.29 \\
20 & -1 & -1 & 1 & 65 & 1 & 5.29 \\
\hline
\end{tabular}

\subsubsection{Kinetics of Esterification Reaction}

A pseudo-homogeneous model was adapted for the evaluation of the kinetics of the R.trisperma oil esterification. This model was selected as it has been widely used in the study of esterification kinetics $[16,17]$. The assumptions held in the development of a pseudo-homogeneous model are as follows [17]: 
- Mass transfer and adsorption/desorption are neglected;

- The methanol concentration is high enough to ensure a constant concentration of methanol throughout the reaction;

- Backward reaction is neglected.

Based on these assumptions, a second order pseudo-homogeneous model was developed for the evaluation of the R.trisperma oil esterification. The derivation of the reaction rate equation was performed as follows. The terms A, B, and C refer to FFA, methanol, and catalyst, respectively. The terms $k, W, X$, and $C$ represent the kinetics constant, weight, conversion, and concentration, respectively. By substituting $C_{A}=C_{A 0}\left(1-X_{A}\right)$ and $C_{B}=C_{B 0}-C_{A 0} X_{A}$, Equation (4) can be rearranged in terms of the conversion of $A$ to construct a linearized equation, as shown in Equation (5). The term $\mathrm{M}$ refers to $\mathrm{C}_{\mathrm{B} 0} / \mathrm{C}_{\mathrm{A} 0}$.

$$
\begin{gathered}
F F A+M e O H \leftrightarrow F A M E+H_{2} O \\
r_{A}=-\frac{d C_{A}}{d t}=k_{1} W_{c} C_{A} C_{B} \\
\int \frac{d X_{A}}{d t}=\int k_{1} W_{c} C_{A o}\left(1-X_{A}\right)\left[\frac{C_{B o}}{C_{A o}}-X_{A}\right] \\
\frac{\ln \left(M-X_{A}\right)-\ln M\left(1-X_{A}\right)}{M-1}=k_{1} W_{c} C_{A o} t+C
\end{gathered}
$$

\subsubsection{Acid Value Analysis}

The acid value analysis procedure was adapted from the EN ISO 66 standard. Approximately $1 \mathrm{~mL}$ of oil sample was mixed with $1 \mathrm{~mL}$ of distilled water inside a $2 \mathrm{~mL}$ micro tube followed by centrifugation. Around $0.5 \mathrm{~g}$ of the washed oil was mixed with $20 \mathrm{~mL}$ of benzene and ethanol mixture $(1: 1 \mathrm{v} / \mathrm{v})$. The solution was titrated with $\mathrm{KOH}$ as the titrant and phenolphthalein as the indicator of the end point of titration. The calculation of the acid value was performed according to Equation (6) shown below. The terms $V, C$, and $m$ represent the volume of $\mathrm{KOH}(\mathrm{mL})$, the concentration of $\mathrm{KOH}$ $(\mathrm{g} / \mathrm{mol})$, and the mass of oil $(\mathrm{g})$, respectively.

$$
\text { Acid Value }=\frac{56.11 \times V \times C}{m}
$$

\section{Results and Discussion}

\subsection{Optimization of Esterification Reaction}

The experimental data obtained are shown in Table 3. A response equation was constructed based on the experimental data by fitting it to a second order polynomial equation through a multiple regression analysis. The quality of the developed model was analyzed based on several parameters including p-value, F-value, coefficient of determination $\left(R^{2}\right)$, and lack of fit. It can be seen in the table that the acid value of the esterified oil was in the range of $1.239-19.534 \mathrm{mg} \mathrm{KOH} / \mathrm{g}$. In order to understand the impact of each input variable on the response variable, an ANOVA was performed, the results of which are shown in Table 4.

The significance of a factor can be represented statistically by its $p$-value with a p-value $<0.05$ indicating high significance and a p-value $>0.1$ indicating low significance or irrelevance of that factor. Based on our ANOVA results, it was clear that the developed model has a high F-value (111.29) and a low p-value (0.000), both of which are indicative of a high fit with the experimental data. This is further backed up by the high value of $R^{2}(0.9901)$, which means that up to only $0.99 \%$ of the variation in the acid value of the esterified model oil could not be explained by the constructed model. The high value of the predicted $R^{2}(0.9337)$ also supports this claim. The low lack of fit F-value (3.86) relative to 
the model F-value (111.29) and the high p-value of the lack of fit (0.086) also imply that the model had a good fit with the experimental data.

Table 3. Experimental matrix and results of model oil esterification.

\begin{tabular}{|c|c|c|c|c|c|c|c|}
\hline \multirow{2}{*}{ Run No } & \multicolumn{3}{|c|}{ Coded Value } & \multicolumn{3}{|c|}{ Real Value } & \multirow{2}{*}{$\begin{array}{l}\text { Acid Value } \\
\text { (mg KOH/g) }\end{array}$} \\
\hline & $\mathbf{A}$ & B & $\mathrm{C}$ & $\mathrm{A}\left({ }^{\circ} \mathrm{C}\right)$ & B (\%wt) & $\mathrm{C}$ & \\
\hline 1 & -1.68 & 0 & 0 & 58.2 & 3 & 3.97 & 13.637 \\
\hline 2 & 0 & 0 & 0 & 75 & 3 & 3.97 & 6.618 \\
\hline 3 & 1 & -1 & 1 & 85 & 1 & 5.29 & 8.142 \\
\hline 4 & 0 & 0 & 0 & 75 & 3 & 3.97 & 6.581 \\
\hline 5 & -1 & -1 & -1 & 65 & 1 & 2.64 & 18.804 \\
\hline 6 & 0 & 0 & 1.68 & 75 & 3 & 6.18 & 4.716 \\
\hline 7 & 1 & 1 & -1 & 85 & 5 & 2.64 & 3.941 \\
\hline 8 & 0 & 0 & -1.68 & 75 & 3 & 1.74 & 12.692 \\
\hline 9 & 0 & 0 & 0 & 75 & 3 & 3.97 & 6.637 \\
\hline 10 & 1 & -1 & -1 & 85 & 1 & 2.64 & 12.380 \\
\hline 11 & 0 & -1.68 & 0 & 75 & 0.36 & 3.97 & 19.534 \\
\hline 12 & -1 & 1 & -1 & 65 & 5 & 2.64 & 11.702 \\
\hline 13 & 1.68 & 0 & 0 & 91.8 & 3 & 3.97 & 3.484 \\
\hline 14 & 0 & 0 & 0 & 75 & 3 & 3.97 & 7.719 \\
\hline 15 & 0 & 1.68 & 0 & 75 & 5.36 & 3.97 & 4.044 \\
\hline 16 & 0 & 0 & 0 & 75 & 3 & 3.97 & 6.598 \\
\hline 17 & 0 & 0 & 0 & 75 & 3 & 3.97 & 6.968 \\
\hline 18 & 1 & 1 & 1 & 85 & 5 & 5.29 & 1.239 \\
\hline 19 & -1 & 1 & 1 & 65 & 5 & 5.29 & 6.648 \\
\hline 20 & -1 & -1 & 1 & 65 & 1 & 5.29 & 15.273 \\
\hline
\end{tabular}

Table 4. ANOVA results of model oil esterification.

\begin{tabular}{cccccc}
\hline Source & DF & Adj SS & Adj MS & F-Value & $p$-Value \\
\hline Model & 9 & 489.144 & 54.349 & 111.29 & 0.000 \\
Linear & 3 & 440.703 & 146.901 & 300.81 & 0.000 \\
A & 1 & 140.476 & 140.476 & 287.66 & 0.000 \\
B & 1 & 238.905 & 238.905 & 489.21 & 0.000 \\
C & 1 & 61.322 & 61.322 & 125.57 & 0.000 \\
Square & 3 & 48.084 & 16.028 & 32.82 & 0.000 \\
A $^{2}$ & 1 & 4.924 & 4.924 & 10.08 & 0.000 \\
B $^{2}$ & 1 & 42.390 & 42.930 & 87.91 & 0.010 \\
C $^{2}$ & 1 & 5.815 & 5.815 & 11.91 & 0.006 \\
2-way & 3 & 0.357 & 0.119 & 0.24 & 0.849 \\
interaction & 1 & 0.019 & 0.019 & 0.04 & 0.425 \\
AB & 1 & 0.338 & 0.338 & 0.69 & 0.995 \\
AC & 1 & 0.000 & 0.000 & 0.00 & 0.082 \\
BC & 10 & 4.883 & 0.488 & 3.86 & \\
Error & 5 & 3.879 & 0.776 & & \\
Lack of fit & 5 & 1.004 & 0.201 & & \\
Pure Error & 19 & 494.027 & & & \\
Total & & & & & \\
\hline
\end{tabular}

The relationship of the predicted and actual acid values of the esterified model oil, which is shown in Figure 2, exhibited a good fit as well, thus also supporting the good fit of the developed model to the experimental data.

According to the ANOVA results, all of the individual factors of the input variables had a significant impact on the acid value of the esterified model oil with a confidence level of $95 \%$. This was inferred from the $\mathrm{p}$-values of the individual factors, all of which were lower than 0.05 . Among these factors, catalyst loading was found to have the most dominant impact on the acid value of the esterified oil, followed by temperature and methanol-to-oil molar ratio respectively (from highest F-value to lowest). The two-way interaction of the individual factors, however, was found to have no significant 
impact on the acid value of the esterified model oil as the p-value was higher than 0.01 for all of the variations.

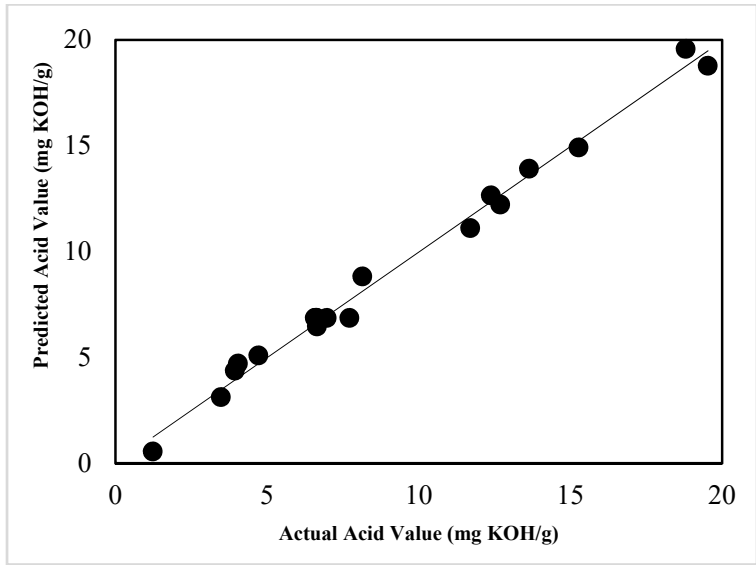

(a)

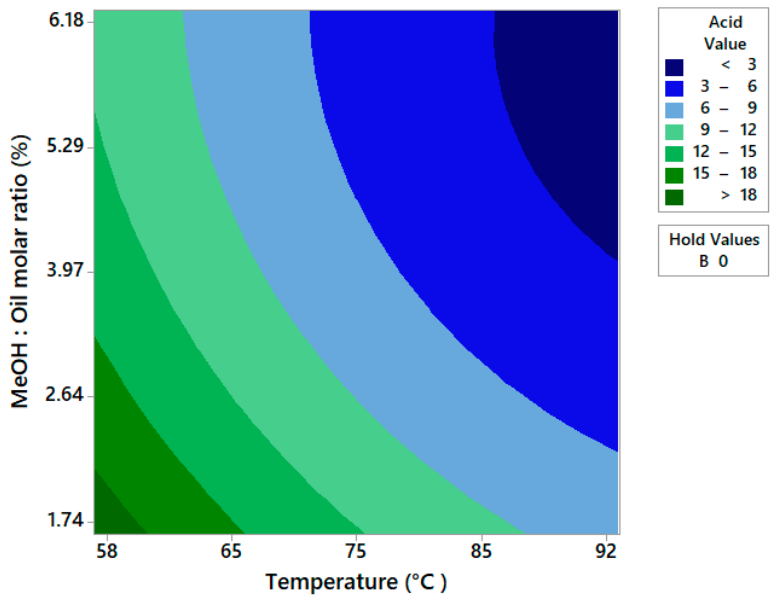

(c)

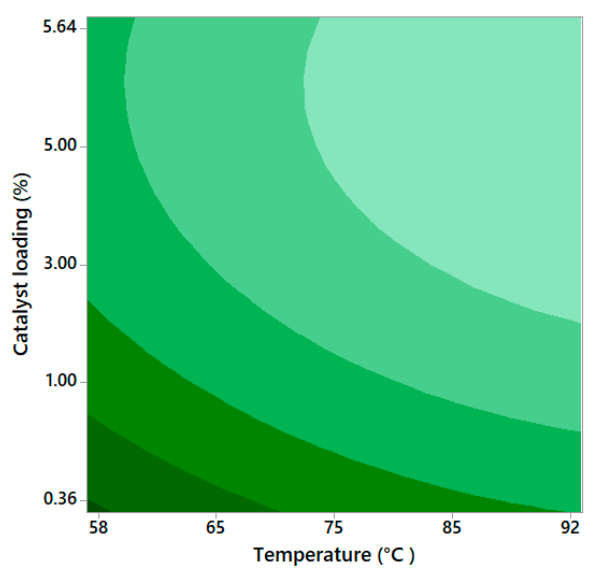

(b)

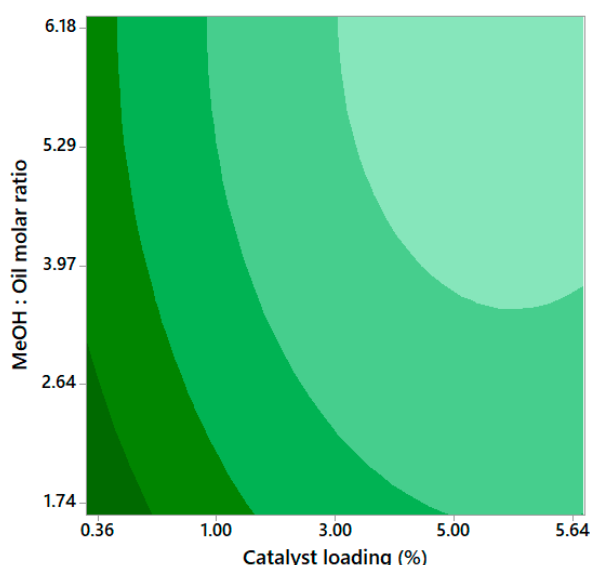

(d)
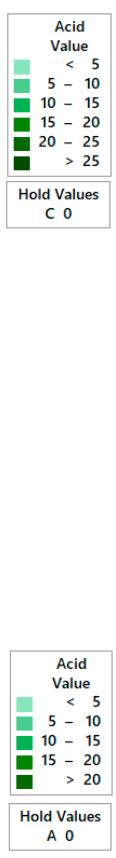

Figure 2. (a) Correlation between predicted and actual acid values of esterified model oil; response contour plot of acid value as a function of (b) temperature and catalyst loading, (c) temperature and methanol-to-oil molar ratio, and (d) catalyst loading and methanol-to-oil molar ratio.

The impacts the input variables had on the response variable can be seen in Figure $2 b, c, d$. An increase in reaction temperature led to a decrease of acid value. This phenomenon could be observed for all of the different catalyst loading inputs (Figure 2b) and different methanol-to-oil molar ratios (Figure 2c). One study performed with palm kernel oil revealed that the increase of temperature reaction from 40 to $60^{\circ} \mathrm{C}$ led to a decrease of acid value, especially at a lower catalyst amount [18]. In the present study, the synergistic impact of either catalyst loading or methanol-to-oil molar ratio with temperature to the acid value of the esterified oil could not be determined. In fact, based on the ANOVA result, the two-way interaction of temperature with either catalyst loading or the methanol-to-oil molar ratio was determined to be a statistically insignificant factor.

The impact the catalyst loading had on the acid value of the esterified model oil can be seen in Figure $2 b$,d. It can be inferred from both figures that the impact was significant. A higher amount of catalyst available in the system increased the active surface area available for reaction, thereby increasing the possibility of a catalytic reaction to occur, the occurrence of which decreased the acid value of the esterified oil. The impact of catalyst loading on the acid value of the esterified oil was independent of both temperature and methanol-to-oil ratio, which was confirmed statistically by the ANOVA result. The esterification of waste cooking oil with Amberlyst-15 (Rohm \& Haas, USA) in an 
earlier study showed a similar trend, the acid value of the esterified oil decreasing as the Amberlyst-15 concentration was increased to $3 \%$ [19].

Based on stoichiometric analysis, the minimum FFA-to-methanol ratio required for the esterification reaction is 1:1. Hence, to favor the conversion of FFA to FAME, an excess amount of methanol is usually used in a reaction. The esterification of oleic acid with methanol catalyzed using Amberlyst-46 (Rohm \& Haas, USA) revealed that a higher methanol concentration could increase the FAME concentration only to a certain level and that the conversion would decrease beyond that optimal concentration [20]. It is thought that an excessively high methanol concentration can inhibit the contact of methanol and oleic acid due to the formation of a biphasic system. In the present study, the increase of the methanol-to-oil molar ratio to the maximum level led to a decrease of FFA. In other words, the effect of the methanol-to-oil molar ratio was independent of temperature and catalyst loading.

$$
y=6.856-3.207 A-4.183 B-2.119 C+0.048 A B+0.206 A C-0.002 B C+0.585 A^{2}+1.726 B^{2}+0.635 C^{2}
$$

The optimal conditions for the esterification reaction of the model oil were evaluated by means of Equation (7), obtained through Minitab 17 by minimizing the response target $(Y)$. The optimal conditions obtained (Table 5) were then used to conduct another set of experiments with the model oil and R.trisperma oil for comparison purposes. The acid value profile for both the model oil and the R.trisperma oil system is shown in Figure 3a. For the model oil system, the final acid value was $1.08 \mathrm{mg}$ $\mathrm{KOH} / \mathrm{g}$ with 95.65 of FFA conversion achieved. In the R.trisperma oil system however, the final acid value was $2.49 \mathrm{mg} \mathrm{KOH} / \mathrm{g}$ with $91.75 \%$ conversion achieved. The higher acid value in the R.trisperma oil system was considered to have been caused by the higher impurities and metal ions present in the R.trisperma oil. It was concluded that these impurities had poisoned the catalyst, leading thereby to a decrease in catalytic activity. Indeed, this phenomenon can be seen in Figure 3a. The acid value for both systems was quite similar up to $1 \mathrm{~h}$ of reaction time; thereafter, from $1.5 \mathrm{~h}$, it started to differ, the value for the R.trisperma oil system staying higher to the end of the reaction, indicative of a reduction in catalytic activity.

Table 5. Optimized esterification parameters.

\begin{tabular}{ccc}
\hline Factors & Coded Value & Real Value \\
\hline A (temperature) & 1.68 & $92{ }^{\circ} \mathrm{C}$ \\
B (catalyst loading) & 1.17 & $5.34 \%$ \\
C (methanol-to-oil molar ratio) & 1.41 & $5.82: 1$ \\
\hline
\end{tabular}

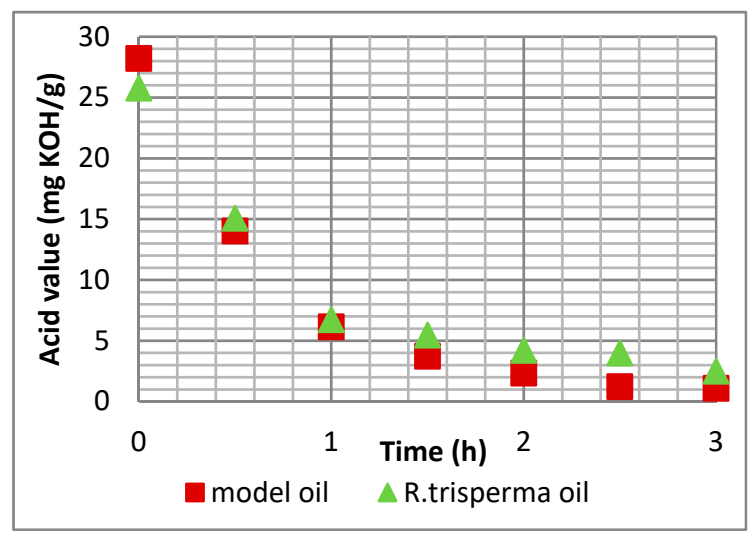

(a)

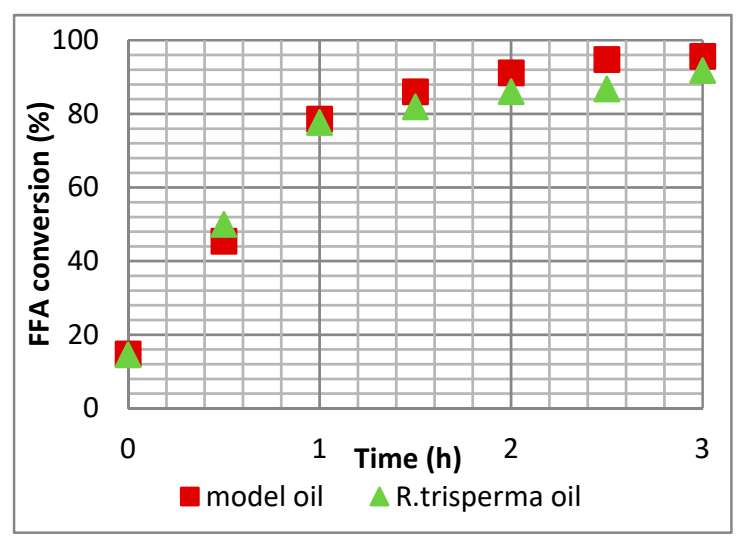

(b)

Figure 3. (a) Acid value profile for model oil and R.trisperma oil esterification; (b) Free fatty acid (FFA) conversion profile for model oil and R.trisperma oil esterification. 


\subsection{Kinetics of Esterification Reaction}

For comparison purposes, the aforementioned kinetics study was performed for both the model oil and the R.trisperma oil. The operating conditions were the same as the optimal conditions shown in Table 5. The catalyst loading and methanol-to-oil molar ratio were set as fixed parameters, while the temperature was varied for the kinetics observation (Table 6). The experimental data obtained were processed according the assumption of pseudo-homogeneous kinetics and the equation elaborated in Section 2 (Equation 3). The experimental data are shown in Figure 4.

Table 6. Operating conditions for kinetics study.

\begin{tabular}{cc}
\hline Factors & Value \\
\hline Temperature $\left({ }^{\circ} \mathrm{C}\right)$ & $65,75,85,95$ \\
Catalyst loading $(\% w t)$ & 5.34 \\
Methanol to oil molar ratio & $5.82: 1$ \\
\hline
\end{tabular}

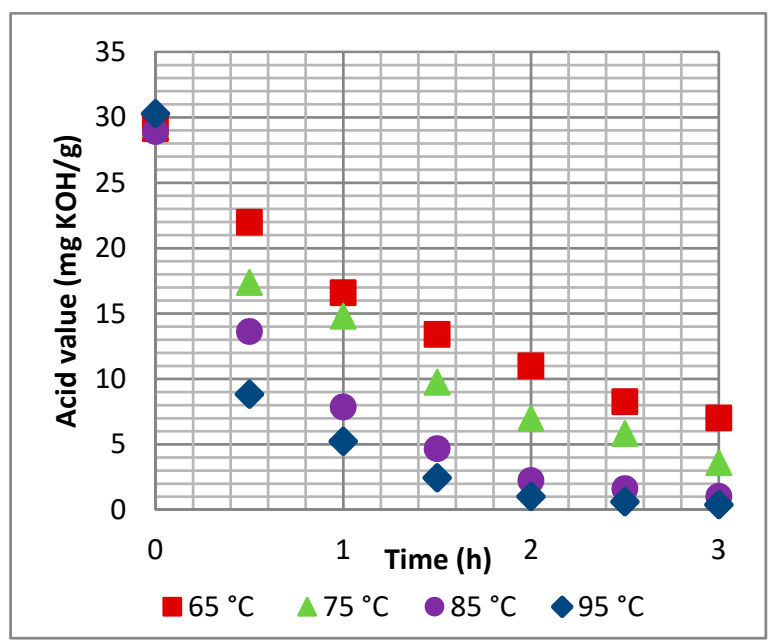

(a)

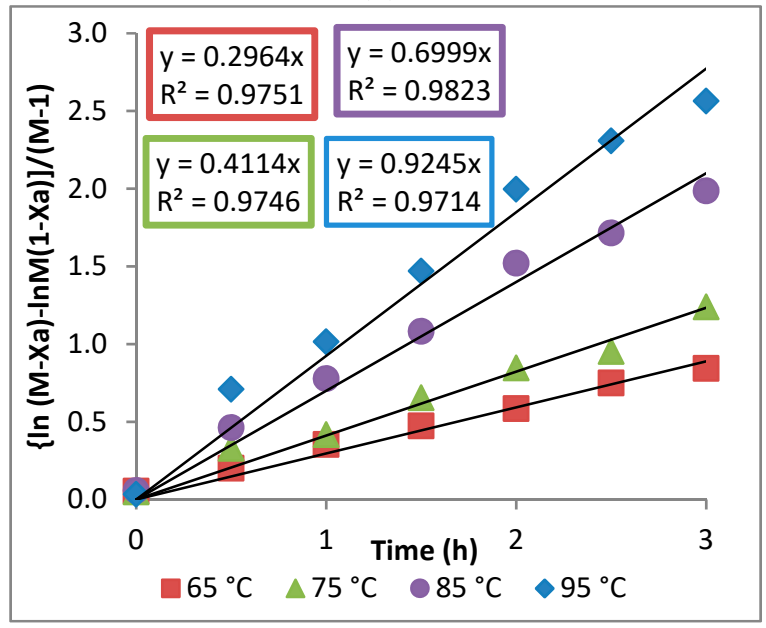

(c)

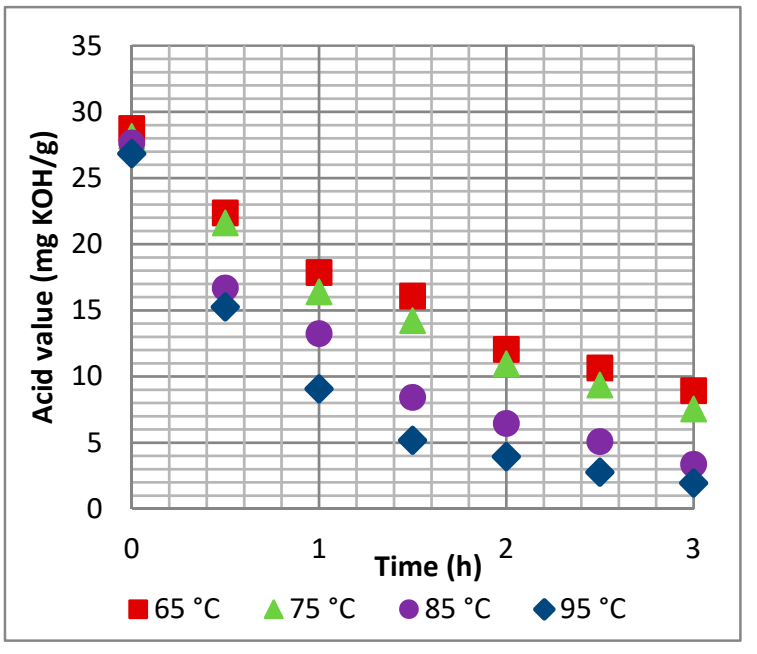

(b)

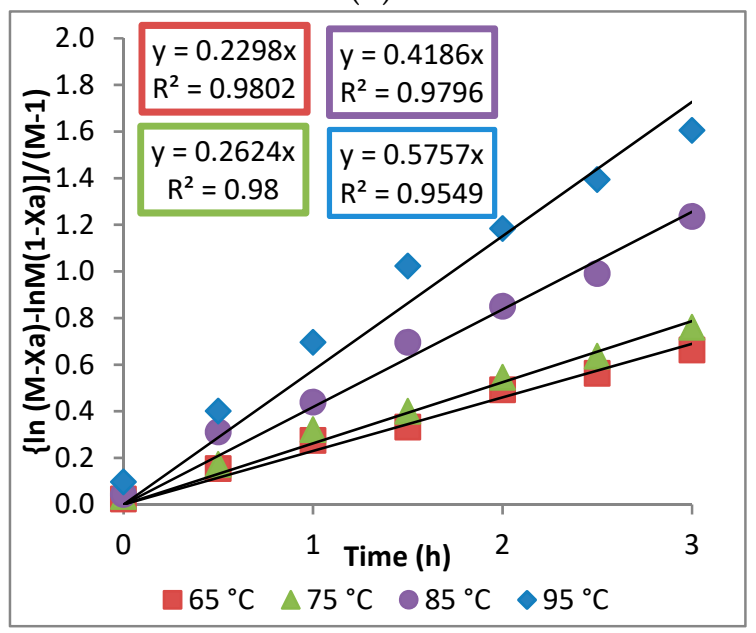

(d)

Figure 4. Acid value profiles of kinetics experiments for (a) model oil system and (b) R.trisperma oil; linearization of experimental data for (c) model oil system and (d) R.trisperma oil system.

At the same temperature, the R.trisperma oil system yielded a lower acid value than that of the model oil system. The lowest acid value was achieved at $95{ }^{\circ} \mathrm{C}$ for both systems, $0.40 \mathrm{mg} \mathrm{KOH} / \mathrm{g}$ for the model oil system, and $1.95 \mathrm{mg} \mathrm{KOH} / \mathrm{g}$ for the R.trisperma oil system. As previously explained, 
this difference is thought to have been caused by the impurities of the R.trisperma oil. The linearized experimental data of the two systems are shown in Figure $4 \mathrm{c}$ and $4 \mathrm{~d}$, respectively. It is clearly apparent that the experimental data fit the developed equation well with a high reliability (high $R^{2}$ ), indicating that the developed model could represent the experimental data well and confirming that the esterification reaction followed pseudo-homogenous kinetics. The values of the kinetics constants for both systems are shown in Table 7. The kinetics constants for the model oil system were higher than those for R.trisperma at all temperatures, which served to further confirm the catalytic activity reduction in the R.trisperma oil system. The activation energy required for the esterification reaction of both systems was derived from an Arrhenius plot, as shown in Figure 5.

Table 7. Kinetics constants for model oil and R.trisperma oil esterification reactions.

\begin{tabular}{ccc}
\hline \multirow{2}{*}{ Temperature (K) } & \multicolumn{2}{c}{$\mathbf{k}_{\mathbf{1}}\left(\mathbf{L ~}^{\mathbf{- 1}} \mathbf{~ m o l}^{-\mathbf{1}} \mathbf{~ m i n}^{-\mathbf{1}}\right)$} \\
\cline { 2 - 3 } & Model Oil & R.Trisperma Oil \\
\hline 338 & 0.03925 & 0.0304 \\
348 & 0.05448 & 0.0348 \\
358 & 0.09269 & 0.0554 \\
368 & 0.12244 & 0.0762 \\
\hline
\end{tabular}

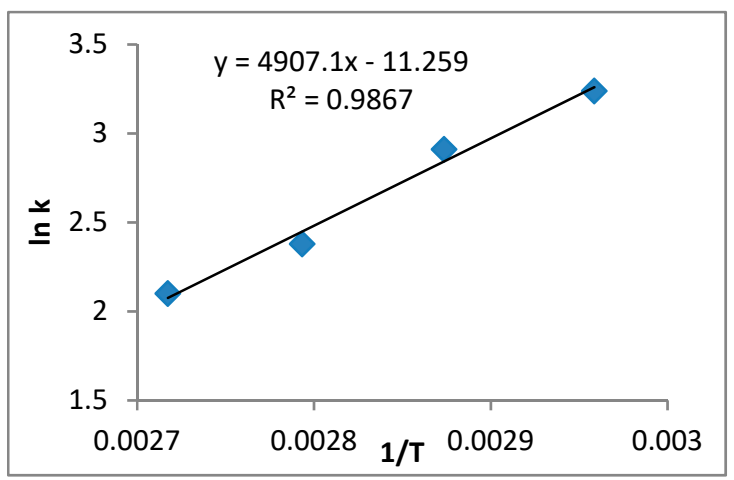

(a)

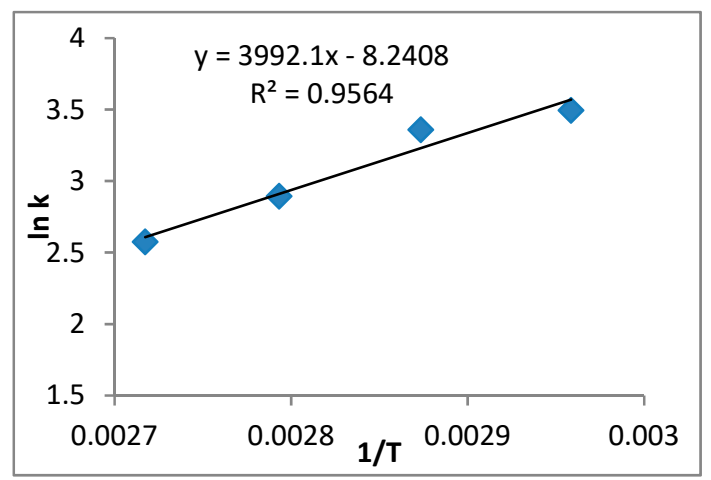

(b)

Figure 5. Arrhenius plots for (a) model oil system, (b) R.trisperma oil system.

The activation energy required for the model oil system was revealed to be $40.8 \mathrm{~kJ} / \mathrm{mol}$. The esterification of oleic acid with ethanol as catalyzed using a sulfonated ion exchange resin at a $47 \%$ catalyst loading in a previous study had an activation energy of $24.80 \mathrm{~kJ} / \mathrm{mol}$ [21], which is much lower than the values determined in the present study. This could be due to the different types of alcohol used (methanol vs. ethanol) as well as the catalyst concentration difference ( $5.34 \%$ vs. $47 \%$ ). In addition, the catalyst used in that study had a higher surface area $\left(46 \mathrm{~m}^{2} / \mathrm{g}\right)$ than the one utilized in the present study $\left(33 \mathrm{~m}^{2} / \mathrm{g}\right)$. Furthermore, the earlier study used pure oleic acid as the feedstock, while this study used a mixture of soybean oil and oleic acid.

The R.trisperma oil system had an activation energy of $33.2 \mathrm{~kJ} / \mathrm{mol}$, which is lower than that of the model oil system. This could be explained by the difference in the fatty acid compositions of the feedstocks. The model oil system contained only oleic acid (C18), while the R.trisperma oil was comprised of several fatty acids ranging from palmitic acid (C16) to docosanoic acid (C22). Additionally, the fatty acid chain length was found to have an impact on the activation energy of the FFA esterification reaction, a longer chain requiring higher activation energy (Table 8) [22]. 
Table 8. Effect of fatty acid chain length on activation energy of esterification reaction [22].

\begin{tabular}{cc}
\hline Fatty Acid & Ea $\times \mathbf{1 0}^{\mathbf{3}} \mathbf{( \mathbf { k J } / \mathbf { k m o l } )}$ \\
\hline Lauric acid (C12) & 36.15 \\
Myristic acid (C14) & 44.00 \\
Palmitic acid (C16) & 45.40 \\
Stearic acid (C18) & 50.10 \\
\hline
\end{tabular}

\section{Conclusions}

The esterification of R.trisperma oil was evaluated and optimized statistically using a response surface methodology via a central composite design with a model oil for optimization of esterification reaction conditions. It was revealed that all of the individual factors (temperature, catalyst loading, and methanol-to-oil molar ratio) observed in this study had a significant impact on the acid value of the esterified oil, catalyst loading having the most significant impact, followed by temperature and methanol-to-oil molar ratio, respectively. The two-way interaction of the individual factors did not have any impact on the acid value of the esterified oil. The developed model could represent the experimental data well with high reliability. Based on the optimization process, the optimal conditions for the esterification reaction of R.trisperma oil were $92{ }^{\circ} \mathrm{C}$ temperature, $5.34 \mathrm{wt} \%$ catalyst loading, and 5.82:1 methanol-to-oil molar ratio, with a final acid value of $2.49 \mathrm{mg} \mathrm{KOH} / \mathrm{g}$ and an achieved FFA conversion of $91.75 \%$.

The kinetics of R.trisperma were investigated under the assumption of pseudo-homogeneous second-order kinetics. It was discovered that the experimental data could fit the developed reaction rate equation well and with high reliability, indicating that the kinetics of R.trisperma oil esterification followed a pseudo-homogeneous second-order reaction under the specified conditions. The activation energy required for the esterification of R.trisperma oil was $33.2 \mathrm{~kJ} / \mathrm{mol}$.

Author Contributions: Conceptualization, R.L.; D.-K.K. and J.-S.L.; Methodology, R.L. and D.-K.K.; Software, R.L.; Resources, R.L. and D.-K.K.; Formal analysis, R.L.; Investigation, R.L.; Data curation, R.L.; Writing一original draft preparation, R.L.; Writing-review and editing, R.L.; D-K.K and J.-S.L.; Visualization, R.L. and D.-K.K.; Supervision, D.-K.K. and J.-S.L.; Project administration, D.-K.K.; Funding acquisition, D.-K.K. All authors have read and agreed to the published version of the manuscript.

Funding: This work was supported by Korea Institute of Energy Technology Evaluation and Planning (KETEP) grant funded by the Korean Government (MOTIE) —Project No. 20178520091280.

Conflicts of Interest: The authors declare no conflict of interest.

\section{References}

1. Seungchan, C. Republic of Korea-2018 Update: Bioenergy Policies and Status of Implementation, IEA Bioenergy. Available online: https://www.ieabioenergy.com/iea-publications/country-reports/2018country-reports/ (accessed on 25 October 2019).

2. Knothe, G.; Sharp, C.A.; Ryan, T.W. Exhaust Emissions of Biodiesel, Petrodiesel, Neat Methyl Esters, and Alkanes in a New Technology Engine. Energy Fuels 2006, 20, 403-408. [CrossRef]

3. Yusuf, N.N.A.N.; Kamarudin, S.K.; Yakuub, Z. Overview on the Current Trends in Biodiesel Production. Energy Convers. Manag. 2011, 52, 2741-2751. [CrossRef]

4. Phan, A.N.; Phan, T.M. Biodiesel Production from Waste Cooking Oils. Fuel 2008, 87, 3490-3496. [CrossRef]

5. Lotero, E.; Liu, Y.; Lopez, D.E.; Suwannakarn, K.; Bruce, D.A.; Goodwin, J.G. Synthesis of Biodiesel Via Acid Catalysis. Ind. Eng. Chem. Res. 2005, 44, 5353-5363. [CrossRef]

6. Schuchardt, U.; Sercheli, R.; Vargas, R.M. Transesterification of Vegetable Oils: A Review. J. Braz. Chem. Soc. 1998, 9, 199-2103. [CrossRef]

7. Atadashi, I.M.; Aroua, M.K.; Aziz, A.A. Biodiesel Separation and Purification: A Review. Renew. Energy 2010, 36, 437-443. [CrossRef]

8. Gui, M.M.; Lee, K.T.; Bhatia, S. Feasibility of Edible Oil Vs. Non-Edible Oil Vs. Waste Edible Oil as Biodiesel Feedstock. Energy 2008, 33, 1646-1653. [CrossRef] 
9. Akinoso, R.; Igbeka, J.; Olayanju, T.; Bankole, L. Modeling of Oil Expression from Palm Kernel (Elaeis Guineensis Jacq.); International Commission of Agricltural Engineering: Liège, Belgium, 2006.

10. Woittiez, L.S.; van Wijk, M.T.; Slingerland, M.; van Noordwijk, M.; Giller, K.E. Yield Gaps in Oil Palm: A Quantitative Review of Contributing Factors. Eur. J. Agron. 2017, 83, 57-77. [CrossRef]

11. Leung, D.Y.; Wu, X.; Leung, M.K.H. A Review on Biodiesel Production Using Catalyzed Transesterification. Appl. Energy 2010, 87, 1083-1095. [CrossRef]

12. Martín, C.; Moure, A.; Martín, G.; Carrillo, E.; Domínguez, H.; Parajo, J.C. Fractional Characterisation of Jatropha, Neem, Moringa, Trisperma, Castor and Candlenut Seeds as Potential Feedstocks for Biodiesel Production in Cuba. Biomass Bioenergy 2010, 34, 533-538. [CrossRef]

13. Nurjanah, S.; Lestari, D.S.; Widyasanti, A.; Zain, S. The Effect of Naoh Concentration and Length of Transesterification Time on Characteristic of Fame from Reutealis Trisperma (Kemiri Sunan). Int. J. Adv. Sci. Eng. Inf. Technol. 2015, 5, 52-56. [CrossRef]

14. Holilah, H.; Prasetyoko, D.; Oetami, T.P.; Santosa, E.B.; Zein, Y.M.; Bahruji, H.; Fansuri, H.; Ediati, R.; Juwari, J. The Potential of Reutealis Trisperma Seed as a New Non-Edible Source for Biodiesel Production. Biomass Convers. Biorefinery 2015, 5, 347-353. [CrossRef]

15. Silitonga, A.S.; Mahlia, T.M.I.; Kusumo, F.; Dharma, S.; Sebayang, A.H.; Sembiring, R.W.; Shamsuddin, A.H. Intensification of Reutealis Trisperma Biodiesel Production Using Infrared Radiation: Simulation, Optimisation, and Validation. Renew. Energy 2019, 133, 520-527. [CrossRef]

16. Cheng, Y.; Feng, Y.; Ren, Y.; Liu, X.; Gao, A.; He, B.; Yan, F.; Li, J. Comprehensive Kinetic Studies of Acidic Oil Continuous Esterification by Cation-Exchange Resin in Fixed Bed Reactors. Bioresour. Technol. 2012, 113, 65-72. [CrossRef] [PubMed]

17. Berrios, M.; Martín, M.A.; Chica, A.F.; Martín, A. Study of Esterification and Transesterification in a Biodiesel Production from Used Frying Oils in a Closed System. Chem. Eng. J. 2010, 160, 473-479. [CrossRef]

18. Kostić, M.D.; Veličković, A.V.; Joković, N.M.; Stamenković, O.S.; Veljković, V.B. Optimization and Kinetic Modeling of Esterification of the Oil Obtained from Waste Plum Stones as a Pretreatment Step in Biodiesel Production. Waste Manag. 2016, 48, 619-629. [CrossRef] [PubMed]

19. Boz, N.; Degirmenbasi, N.; Kalyon, D.M. Esterification and Transesterification of Waste Cooking Oil over Amberlyst 15 and Modified Amberlyst 15 Catalysts. Appl. Catal. B Environ. 2015, 165, 723-730. [CrossRef]

20. Ilgen, O. Investigation of Reaction Parameters, Kinetics and Mechanism of Oleic Acid Esterification with Methanol by Using Amberlyst 46 as a Catalyst. Fuel Process. Technol. 2014, 124, 134-139. [CrossRef]

21. Jiang, Y.; Lu, J.; Sun, K.; Ma, L.; Ding, J. Esterification of Oleic Acid with Ethanol Catalyzed by Sulfonated Cation Exchange Resin: Experimental and Kinetic Studies. Energy Convers. Manag. 2013, 76, 980-985. [CrossRef]

22. Banchero, M.; Gozzelino, G. A Simple Pseudo-Homogeneous Reversible Kinetic Model for the Esterification of Different Fatty Acids with Methanol in the Presence of Amberlyst-15. Energies 2018, 11, 1843. [CrossRef] 